\title{
Expression of estrogen, estrogen related and androgen receptors in adrenal cortex of intact adult male and female rats
}

\author{
Marcin Trejter, Karol Jopek, Piotr Celichowski, Marianna Tyczewska, \\ Ludwik K. Malendowicz, Marcin Rucinski
}

Department of Histology and Embryology, Poznan University of Medical Sciences, Poznan, Poland

\begin{abstract}
Introduction. Adrenocortical activity in various species is sensitive to androgens and estrogens. They may affect adrenal cortex growth and functioning either via central pathways (CRH and ACTH) or directly, via specific receptors expressed in the cortex and/or by interfering with adrenocortical enzymes, among them those involved in steroidogenesis. Only limited data on expression of androgen and estrogen receptors in adrenal glands are available. Therefore the present study aimed to characterize, at the level of mRNA, expression of these receptors in specific components of adrenal cortex of intact adult male and female rats.

Material and methods. Studies were performed on adult male and female (estrus) Wistar rats. Total RNA was isolated from adrenal zona glomerulosa $(\mathrm{ZG})$ and fasciculate/reticularis $(\mathrm{ZF} / \mathrm{R})$. Expression of genes were evaluated by means of Affymetrix ${ }^{\circledR}$ Rat Gene 1.1 ST Array Strip and QPCR.

Results. By means of Affymetrix ${ }^{\circledast}$ Rat Gene 1.1 ST Array we examined adrenocortical sex differences in the expression of nearly 30,000 genes. All data were analyzed in relation to the adrenals of the male rats. 32 genes were differentially expressed in ZG, and 233 genes in $\mathrm{ZF} / \mathrm{R}$. In the $\mathrm{ZG}$ expression levels of 24 genes were lower and 8 higher in female rats. The more distinct sex differences were observed in the $\mathrm{ZF} / \mathrm{R}$, in which expression levels of 146 genes were lower and 87 genes higher in female rats. Performed analyses did not reveal sex differences in the expression levels of both androgen (AR) and estrogen (ER) receptor genes in the adrenal cortex of male and female rats. Therefore matrix data were validated by QPCR. QPCR revealed higher expression levels of AR gene both in ZG and ZF/R of male than female rats. On the other hand, QPCR did not reveal sex-related differences in the expression levels of $\mathrm{ER} \alpha, \mathrm{ER} \beta$ and non-genomic GPR30 (GPER-1) receptor. Of those genes expression levels of $\mathrm{ER} \alpha$ genes were the highest. In studied adrenal samples the relative expression of $\mathrm{ER} \alpha$ mRNA was higher than $\mathrm{ER} \beta$ mRNA. In adrenals of adult male and female rats expression levels of estrogen-related receptors ERR $\alpha$ and $\mathrm{ERR} \beta$ were similar, and only in the $\mathrm{ZF} / \mathrm{R}$ of female rats ERR $\gamma$ expression levels were significantly higher than in males. We also analyzed expression profile of three isoforms of steroid $5 \alpha$-reductase (Srd5a1, Srd5a2 and Srd5a3) and aromatase (Cyp19a1) and expression levels of all these genes were similar in $\mathrm{ZG}$ and $\mathrm{ZF} / \mathrm{R}$ of male and female rats.

Conclusions. In contrast to Affymetrix microarray data QPCR revealed higher expression levels of AR gene in adrenal glands of the male rats. In adrenals of both sexes expression levels of $\operatorname{ER} \alpha, \operatorname{ER} \beta$, non-genomic GPR30 (GPER-1), ERR $\alpha$ and ERR $\beta$ receptors were comparable. The obtained results suggest that acute steroidogenic effect of estrogens on corticosteroid secretion may be mediated by non-genomic GPR30. (Folia Histochemica et Cytobiologica 2015, Vol. 53, No. 2, 133-144)
\end{abstract}

Key words: rat adrenal cortex; androgen receptor; ER $\alpha$; ER $\beta$; GPR30; GPER-1; ERR $\alpha$; ERR $\beta$; ERR $\gamma$; sex differences

Correspondence address: M. Trejter, M.D., Ph.D.

Department of Histology and Embryology

Poznan University of Medical Sciences

Swiecicki St. 6, 60-781 Poznan

e-mail: mtrejter@ump.edu.pl 


\section{Introduction}

Sex related differences in the structure and function of adrenal gland are well recognized. In this regard both androgen and estrogen receptors (AR, ER; respectively) play an important role in the functioning of the gland and the earliest quantitative data on this subject were extensively reviewed [1]. These early studies revealed that the number of estrogen-binding sites was similar in both male and female adrenals, while the number of androgen-binding sites was notably higher in adrenals of male rats [2-5]. By means of immunohistochemistry androgen receptor-like immunoreactivity was found in fasciculata (ZF) and reticularis $(\mathrm{ZR})$ zones of the rat adrenal cortex while no such reaction was found in the zona glomerulosa (ZG) and adrenal medulla [6, 7]. Furthermore, by means of immunoblot assay relatively high levels of androgen receptors were detected in the adrenal glands of rats of both sexes [8].

Contrary to the androgen receptor, only scanty data were available on topographical expression of estrogen receptor in the rat adrenal gland. In the earliest studies, after the injection of $6,7-{ }^{3} \mathrm{H}$-estradiol-17 $\beta$ Stumpf [9] did not found specific uptake of radioactivity in adrenals of both male and female rats. With advent of molecular biology era new estrogen and estrogen-related receptors (ERRs) were identified. ERR $\alpha$ and $\mathrm{ERR} \beta$ were cloned in 1988 by Giguere et al. [10] while the third member of this group - ERR $\gamma$ was identified in 1999 by Hong et al. [11]. The ERRs belong to the NR3B orphan nuclear receptor subgroup. In the meantime Kuiper et al. [12] identified a new estrogen receptor isoform, named estrogen receptor beta $(\mathrm{ER} \beta)$. Both, $\operatorname{ERR} \alpha$ and $\operatorname{ERR} \beta$ possess high sequence homology to $\operatorname{ER} \alpha$ and $\operatorname{ER} \beta$, respectively. Finally, in 2005 the $\mathrm{G}$ protein coupled receptor (GPR30 or GPER-1) was identified as a non-genomic ER mediating the rapid estrogen-dependent $G$ protein signaling [13, 14]. Only limited data on the expression of these receptors in adrenal glands are available.

Recently, by means of microarray analysis we characterized sex-related gene expression profiles in the adrenal cortex of the mature rat [15]. This study failed to demonstrate differences in expression levels of androgen and estrogen receptor genes in male and female glands. However, the quality of gene expression data obtained from microarrays can vary greatly with the methods used [16]. Therefore microarray data, especially those near expression fold 2 level have to be validated by other methods. In this regard QPCR is considered as the "gold-standard" method of measuring gene expression [17]. Regarding this one report indicated that correlation coefficients (r) for each gene for the agreement between RT-PCR (QPCR) and microarray (Affymetrix platform) ranged from -0.48 to +0.93 [18] .

Therefore, the aim of the present study was to validate earlier obtained Affymetrix microarray data by QPCR [15]. Using this method we characterized at the level of mRNA the expression of ERs, ERRs, GPR30 and AR in specific components of the adrenal cortex of intact adult male and female rats. Moreover, under the same experimental model we studied expression of pivotal genes coding proteins involved in the reactions of testosterone reduction and estrogen aromatization.

\section{Material and methods}

Animals. Adult female and male Wistar rats (12 weeks old, final body weight 120-150 g) were obtained from the Laboratory Animals Breeding Center, Department of Toxicology, Poznan University of Medical Sciences. Animals were maintained under standardized conditions of light (14:10 h light-dark cycle, illumination onset 06.00 a.m.) at $23^{\circ} \mathrm{C}$ with free access to standard food pellets and tap water. Females were used in estrus cycle phase, which was determined according to the cell types observed in the vaginal smear. After decapitation (between 09:00 and 10:00 h), adrenal glands were promptly removed, freed of adherent adipose tissue and processed for study. Briefly, under a stereomicroscope, male and female (in both groups $n=6$ ) rat adrenal glands were decapsulated to separate ZG from the fasciculata/reticularis zones $(\mathrm{ZF} / \mathrm{R})$. Medulla of adrenal gland was removed from the study. The Local Ethics Committee for Animal Studies approved the study protocol. If not otherwise stated, all reagents were obtained from Sigma-Aldrich (St. Louis, MO, USA) or from Avantor Performance Materials Poland SA (Gliwice, Poland).

RNA isolation. RNA isolation from adrenal samples was described earlier [15, 19]. Briefly, we used TRI Reagent (Sigma-Aldrich) and the isolated RNA was purified on columns (Rneasy Mini Kit, Qiagen, Hilden, Germany). The quantity of total RNA was determined spectrophotometrically (optical density at $260 \mathrm{~nm}$ ) and its purity was estimated by $260 / 280 \mathrm{~nm}$ absorption ratio (higher than 1.8) (NanoDrop spectrophotometer, Thermo Scientific, Waltham, MA, USA). RNA integrity and quality were checked on Bioanalyzer 2100 (Agilent Technologies, Inc., Santa Clara, CA, USA). Evaluated RINs (RNA Integrity Numbers) were between 8.5 and 10 with the average of 9.2. RNA concentration in each sample was diluted to $100 \mathrm{ng} / \mu \mathrm{L}$ with OD260/OD280 ratio of 1.8/2.0.

Microarray expression analysis. Microarray expression analysis was also described earlier [15, 20]. Previously iso- 
lated total RNA (100 ng) was mixed with $1.5 \mu \mathrm{L}$ of Poly-A RNA control solution. Such prepared samples were subjected to reverse transcription to synthase first and second strands of cDNA. Obtained cDNA was used as template for in vitro transcription to synthase labeled aRNA (antisense) by incubation at $40^{\circ} \mathrm{C}$ for 16 hours. After purification aRNA was applied for the second round sense cDNA synthesis by WT Expression Kit (Ambion, Austin, TX, USA). The obtained cDNA was used for biotin labeling and fragmentation by Affymetrix GeneChip ${ }^{\circledR}$ WT Terminal Labeling and Hybridization (Affymetrix, Santa Clara, CA, USA). Biotin-labeled fragments of cDNA $(5.5 \mu \mathrm{g})$ were hybridized to Affymetrix ${ }^{\circledast}$ Rat Gene 1.1 ST Array Strip $\left(45^{\circ} \mathrm{C} / 24 \mathrm{~h}\right)$. Each array comprised of more than 720,000 unique 25-mer oligonucleotide probes, which included over 27,000 genes. Up to 25 unique probes' sequences were hybridized to a single transcript. After hybridization, every array strip was washed and stained by Fluidics Station of the GeneAtlas System (Affymetrix). The array strips were scanned by Imaging Station of the GeneAtlas System. Preliminary analysis of the scanned chips was performed using Affymetrix GeneAtlasTM Operating Software. The quality of gene expression data was checked according to the quality control criteria provided by the software. The intensity of fluorescence was transformed to numeric value by generating a CEL file. The obtained CEL files were imported into downstream data analysis software. If not otherwise stated, all of presented analysis and graphs were performed by Bioconductor and R programming language [21]. Each CEL file was merged with a description file (downloaded from Affymetrix webpage). In order to perform background correction, normalization and summarization of the results, we used Robust Multiarray Averaging (RMA) method. Statistical significance of the expression levels of the analyzed genes was examined by moderated t-statistics from the empirical Bayes method. The obtained $\mathrm{p}$ values were corrected for multiple comparisons using the Benjamini and Hochberg's false discovery rate (statistical method incorporated into Bioconductor calculations) [22]. The selection of significantly changed gene expression was based on p value below 0.05 and expression fold higher than \pm 2 . Fold-change calculations were done either for appropriate adrenocortical zones of male and female rats or for $\mathrm{ZG}$ and $\mathrm{ZF} / \mathrm{R}$ of adrenals in both sexes and presented on volcano plots.

QPCR studies. Methods applied were described in our earlier publications [15, 23]. Reverse transcription was performed using AMV reverse transcriptase (Promega, Madison, WI, USA) with Oligo dT (PE Biosystems, Warrington, UK) as primers in the temperature of $42^{\circ} \mathrm{C}$ for 60 min (thermocycler UNO II, Biometra, Goettingen, Germany). The primers used were designed by Primer 3 software (Whitehead Institute for Biomedical Research, Cambridge, UK) (Table 1). The primers were purchased from the Labo-

Table 1. Primers used for the validation of studied genes. Gene symbol, Genebank accession numbers, oligonucleotide sequences for sense and antisense primers, their position on mRNA and product size are shown. HPRT (hypoxanthine phosphorybosyl transferase) was the reference gene

\begin{tabular}{|c|c|c|c|c|c|}
\hline cDNA & Genbank accession number & Primer & Primer sequence (5'-3') & Position & $\begin{array}{l}\text { PCR product } \\
\text { size (bp) }\end{array}$ \\
\hline \multirow[t]{2}{*}{$\mathrm{AR}$} & NM_012502.1 & S & ATCATCTCTGTGCAAGTGCCC & $3634-3654$ & 162 \\
\hline & & A & CCCATGCCAGAGAAGTAGTG & $3776-3795$ & \\
\hline \multirow[t]{2}{*}{$\mathrm{ER} \alpha$} & NM_012689.1 & $\mathrm{S}$ & ATGATGGGCTTATTGACCAAC & $1248-1268$ & 137 \\
\hline & & A & AGGATCTCCAACCAGGCACA & $1365-1384$ & \\
\hline \multirow[t]{2}{*}{$\mathrm{ER} \beta$} & NM_012754.1 & S & TCTGTGTGAAGGCCATGATC & $1474-1493$ & 237 \\
\hline & & A & GCAGATGTTCCATGCCCTTG & $1691-1710$ & \\
\hline \multirow[t]{2}{*}{$\operatorname{ERR} \alpha$} & NM_001008511.2 & S & СТСТСТАСССАААСGССТСТ & $334-353$ & 234 \\
\hline & & A & CGCACACCCTCCTTGAGCAT & $548-567$ & \\
\hline \multirow[t]{2}{*}{$\mathrm{ERR} \beta$} & NM_001008516.2 & $\mathrm{S}$ & CTGGAGCTTTACCGAGCCAT & $952-971$ & 239 \\
\hline & & A & GGCAGTGTCAACAGCAGCTT & $1171-1190$ & \\
\hline \multirow[t]{2}{*}{$\mathrm{ERR} \gamma$} & NM_203336.2 & $S$ & TATCACTATGGGGTTGCCTC & $700-719$ & 222 \\
\hline & & A & CTTGTACTTCTGCCGACCT & $903-921$ & \\
\hline \multirow[t]{2}{*}{ GPR30 } & NM_133573.1 & $S$ & CTTCTGCCATGCCACGCTCA & $1095-1114$ & 57 \\
\hline & & A & ACATCTGACTGCTCCGTGCT & $1132-1151$ & \\
\hline \multirow[t]{2}{*}{ HPRT } & NM_012583 & S & ATTTTGGGGCTGTACTGCTTGA & $391-412$ & 146 \\
\hline & & A & CAGTCAACGGGGGACATAAAAG & $515-536$ & \\
\hline
\end{tabular}




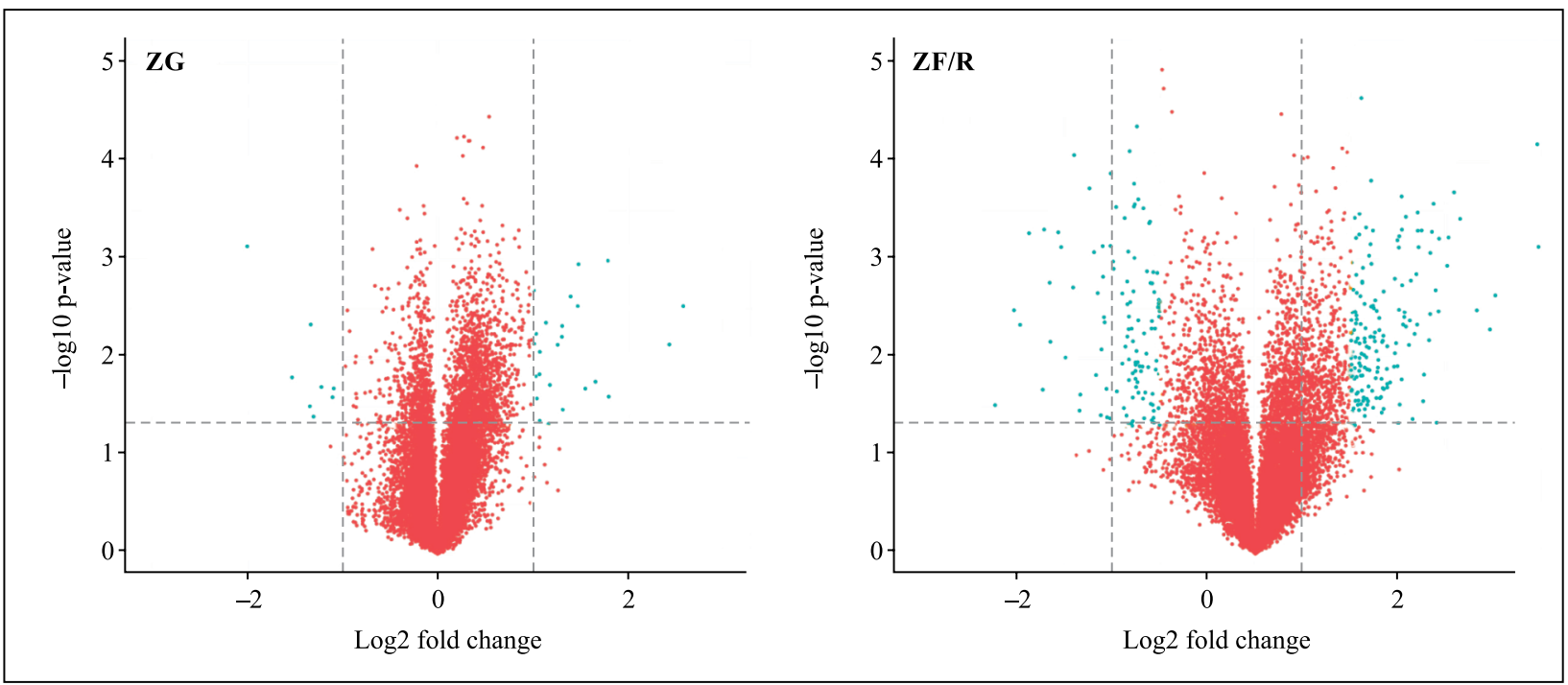

Figure 1. Volcano plot graphs of gender specific differences of genes expression in ZG (zona glomerulosa) and ZF/R (zona fasciculata/reticularis) of adrenals of adult female rats, in relations to adult male rats (Affymetrix ${ }^{\circledR}$ Rat Gene 1.1 ST Array). Orange vertical dotted lines marks fold change cutoff values $(+2,-2$ fold change of expression). Orange horizontal dotted lines point statistical significance cutoff value $(\mathrm{p}<0.05)$. Names of genes have not been shown. Green dots marks genes above cut off the thresholds considering as differentially expressed genes. Red dots refer to the genes below cutoff thresholds and their expression does not differ

ratory of DNA Sequencing and Oligonucleotide Synthesis, Institute of Biochemistry and Biophysics, Polish Academy of Sciences, Warsaw, Poland. QPCR was performed in the Light cycler 2.0 instrument (Roche Diagnostics Corporation, Indianapolis, IN, USA) with the 4.05 software version. Using the above-mentioned primers, SYBR green detection system was applied. $20 \mu \mathrm{L}$ reaction mixtures contained $4 \mu \mathrm{L}$ template cDNA (standard or control), $0.5 \mu \mathrm{M}$ of every gene-specific primer and a previously determined optimum $\mathrm{MgCl}_{2}$ concentration (3.5 $\mu \mathrm{M}$ for one reaction). Light Cycler FastStart DNA Master SYBR Green I mix (Roche) was used. The real-time PCR program included 10 min denaturation step to activate the Taq DNA Polymerase, followed by a three-step amplification program: denaturation at $95^{\circ} \mathrm{C}$ for $10 \mathrm{~s}$, annealing at $56^{\circ} \mathrm{C}$ for $5 \mathrm{~s}$, and extension at $72^{\circ} \mathrm{C}$ for $10 \mathrm{~s}$. The specificity of the reaction products was checked by the determination of melting points $\left(0.1^{\circ} \mathrm{C} / \mathrm{s}\right.$ transition rate). PCR efficiency was assessed by serial dilution method. Products from QPCR reactions were separated in $2 \%$ agarose gel and specific bands were extracted by DNA gel extraction kit (Millipore, Billerica, MA, USA). The amount of the extracted DNA was estimated spectrophotometrically. The extracted DNA was diluted (10-fold serial dilutions) and applied for QPCR in order to obtain standard curve for PCR reaction efficiency calculation. The applied version of Light Cycler software (4.05) allows for the evaluation of amplification efficiency plots.

Statistical methods. QPCR data were expressed as means $\pm \mathrm{SE}$, and the statistical significance of the differences between control and experimental groups was estimated using Student's t-test.

\section{Results}

\section{Microarray analysis}

By means of Affymetrix Rat Gene 1.1 ST Array we examined adrenocortical sex differences in the expression of nearly 30,000 genes. Due to the nature of applied experiment, all data were analyzed in relation to the gene expression level in the adrenals of the male rats. Microarray analyses were performed separately on $\mathrm{ZG}$ and $\mathrm{ZF} / \mathrm{R}$ zones of the adrenal cortex. Firstly, genes which we consider as differentially expressed between sexes, were selected by previously established cutoff criteria (fold change $>$ abs (2) and $p<0.05)$. The mean expression values with relation to $\mathrm{p}$ value were presented in volcano plot graphs (Figure 1). Green dots on the left side of the graphs show genes that expression levels were higher than in male adrenals. Contrary, in the right part of the graphs green dots correspond to genes of lower expression than in male adrenals. Summing up, 32 genes were differentially expressed in $Z G$, and 233 genes in $Z F / R$. In the $Z G$ expression levels of 24 genes were lower and 8 higher in the female rats. The more distinct sex differences in the expression levels of the analyzed genes were observed in the $\mathrm{ZF} / \mathrm{R}$ of the adrenal gland. In these zones the expression levels of 


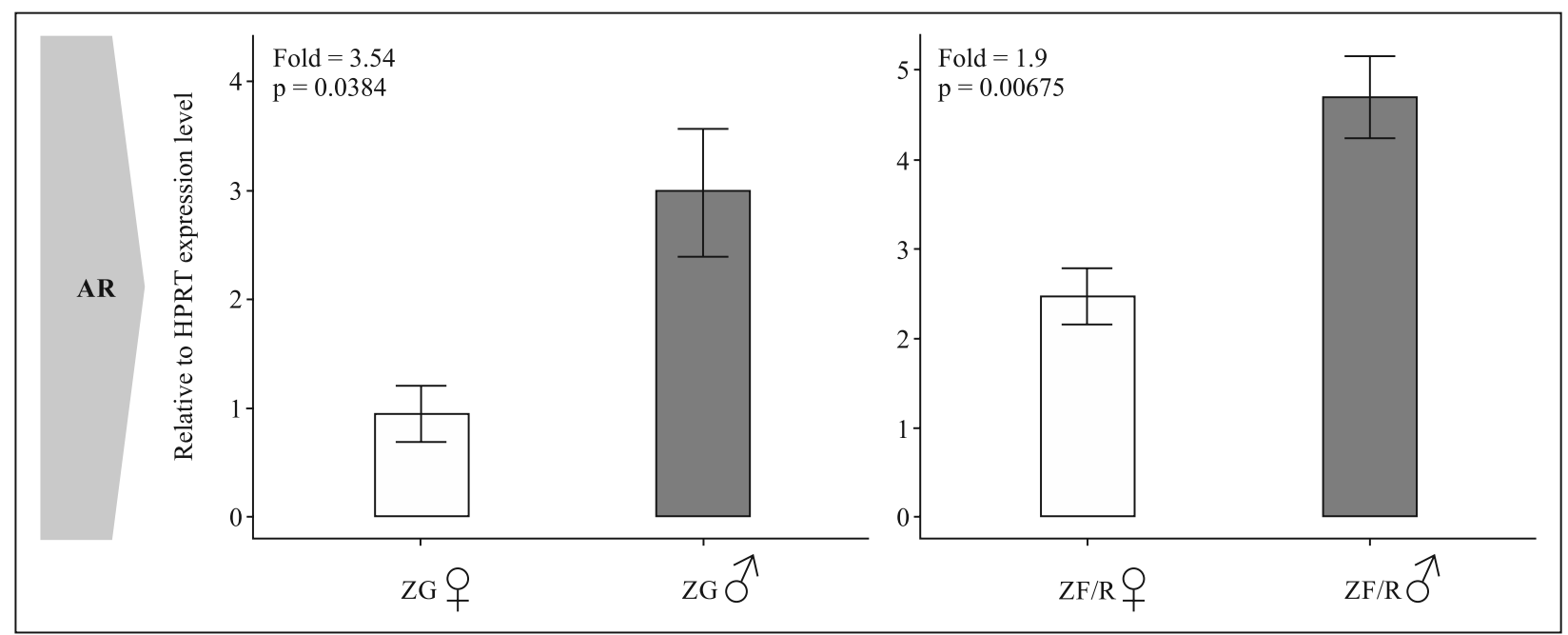

Figure 2. Expression of androgen receptor (AR) in $\mathrm{ZG}$ and $\mathrm{ZF} / \mathrm{R}$ of adult female and male adrenals. Bar plots present means of expression \pm SE, normalized to HPRT reference gene. In each group $n=4$. Data in relation to male adrenals. Fold changes and $\mathrm{p}$ values are shown

146 genes were lower and 87 genes higher in female rats. Of note, the applied microarray method did not reveal sex differences in the expression levels of the studied genes [AR; ER $\alpha$; ER $\beta$; GPR30 (GPER-1), $\operatorname{ERR} \alpha ; \operatorname{ERR} \beta ; \mathrm{ERR} \gamma]$ in the adrenal cortex of male and female rats.

\section{QPCR analysis}

The obtained matrix data were validated in relation to the genes of interest by means of the QPCR technique. This method revealed significantly higher expression levels of AR gene both in $\mathrm{ZG}$ and $\mathrm{ZF} / \mathrm{R}$ of male than female rats (fold 3.54 and 1.9 respectively) (Figure 2). Of interest is that in both male and female adrenal glands, the expression levels of the AR gene were similar in the $\mathrm{ZG}$ and $\mathrm{ZF} / \mathrm{R}$.

In contrast, QPCR did not reveal sex-related differences in the expression levels of $\operatorname{ER} \alpha, \operatorname{ER} \beta$ and GPR30 (Figure 3). Of the studied genes the expression levels of the $\mathrm{ER} \alpha$ gene in rat adrenal cortex were the highest. The relative expression levels of $\mathrm{ER} \alpha / \mathrm{ER} \beta$ were: in $\mathrm{ZG}$ of females $1.48 \pm 0.10$; in males $1.69 \pm 0.72(\mathrm{p}=0.78)$; in $\mathrm{ZF} / \mathrm{R}$ of females $9.33 \pm 1.53$; in males $2.96 \pm 0.69(\mathrm{p}=0.01)(\mathrm{n}=3$; means \pm SE). In the adrenal cortex of adult male and female rats the expression levels of $\mathrm{ERR} \alpha$ and $\mathrm{ERR} \beta$ genes were similar, however, in $\mathrm{ZF} / \mathrm{R}$ of female rats the expression level of ERR $\gamma$ was significantly higher than in males (Figure 4).

Since all our QPCR studies were performed on the same sample set in relation to the same reference gene, and additionally with respect to the PCR effi- ciency, we were able to compare expression profiles of all analyzed genes. It appeared that in rat adrenal gland the relative expression levels (rel) of AR gene are the highest (rel from 1 to approximately 5) and followed by $\operatorname{ER} \alpha$ (rel 0.4-0.9). Moderate expression levels were found in case of $\operatorname{ERR} \alpha, \operatorname{ERR} \beta$ and $\operatorname{ERR} \gamma$ genes (rel 0.05-0.1) while the lowest expression was found for $\mathrm{ER} \beta$ and GPR30 (rel 0.015-0.04).

Moreover, based on the data of the matrix study we analyzed expression profiles of genes which encode three isoforms of steroid $5 \alpha$-reductase (Srd5a1, Srd5a2 and Srd5a3), an enzyme system catalyzing conversion of steroids to $5 \alpha$-dihydrosteroids, as well as gene encoding aromatase (Cyp19a1), an enzyme involved in the transformation of androgens into estrogens. We found that the expression levels of all these genes were similar in $\mathrm{ZG}$ and $\mathrm{ZF} / \mathrm{R}$ of male and female rats (Figure 5).

\section{Discussion}

It is well known that adrenocortical activity in the rat, like in other mammals, is sensitive to androgens and estrogens [1,24, 25]. These hormones may affect adrenal cortex growth and function either via central pathways (hypothalamic CRH and adenohypophyseal ACTH) or — with great probability - directly, via specific receptors expressed in the cortex and/or by interfering with adrenocortical enzymes, among them those involved in steroidogenesis.

The expression of AR in the rat adrenal gland is well known. The early studies revealed that the number of androgen-binding sites was notably higher 


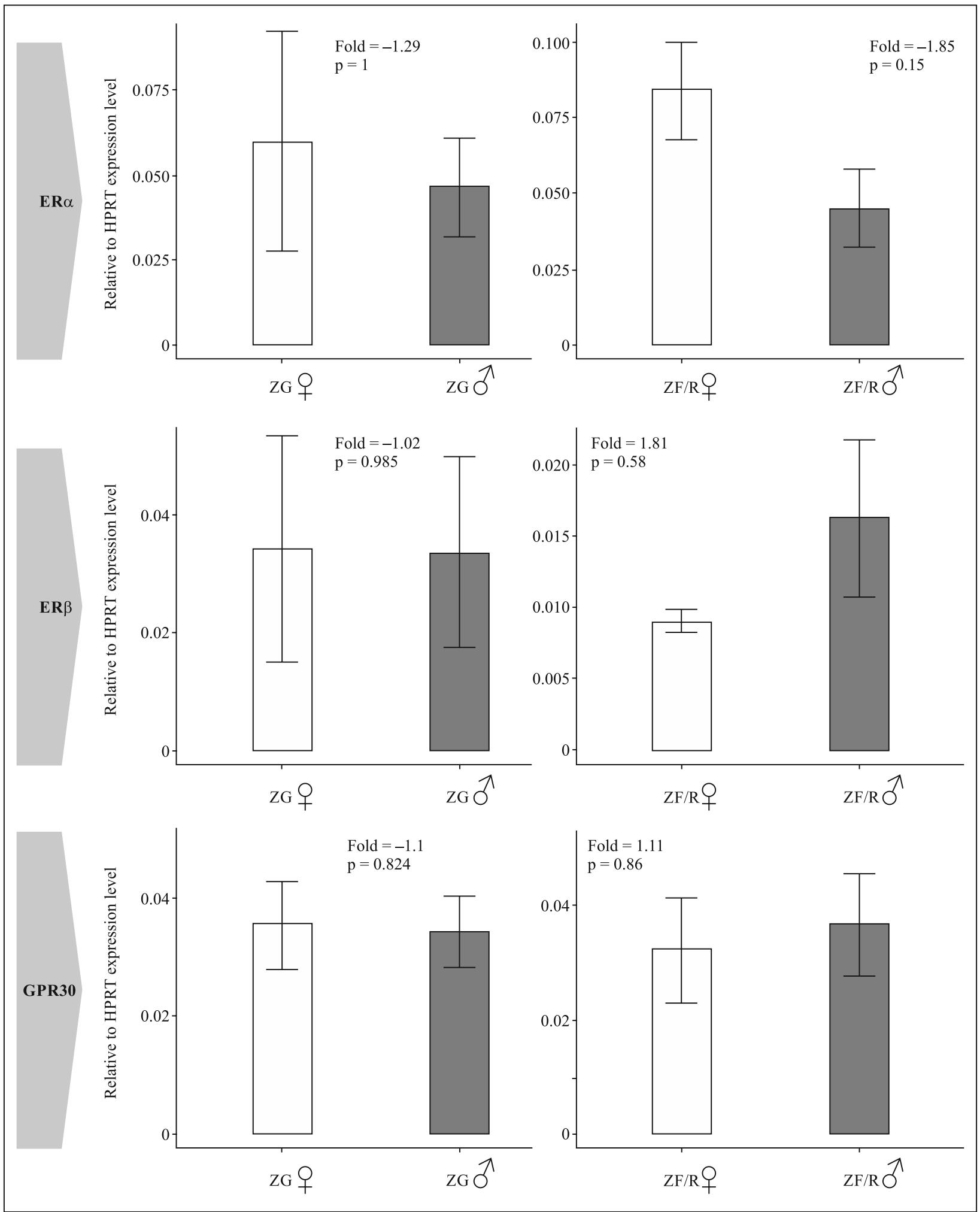

Figure 3. Expression of estrogen receptors ( $\mathrm{ER} \alpha, \mathrm{ER} \beta$ and GPR30) in $\mathrm{ZG}$ and $\mathrm{ZF} / \mathrm{R}$ of adult female and male adrenals. Bar plots present means of expression \pm SE, normalized to HPRT reference gene. In each group $n=3$. Data in relation to male adrenals. Fold changes and $p$ values are shown 


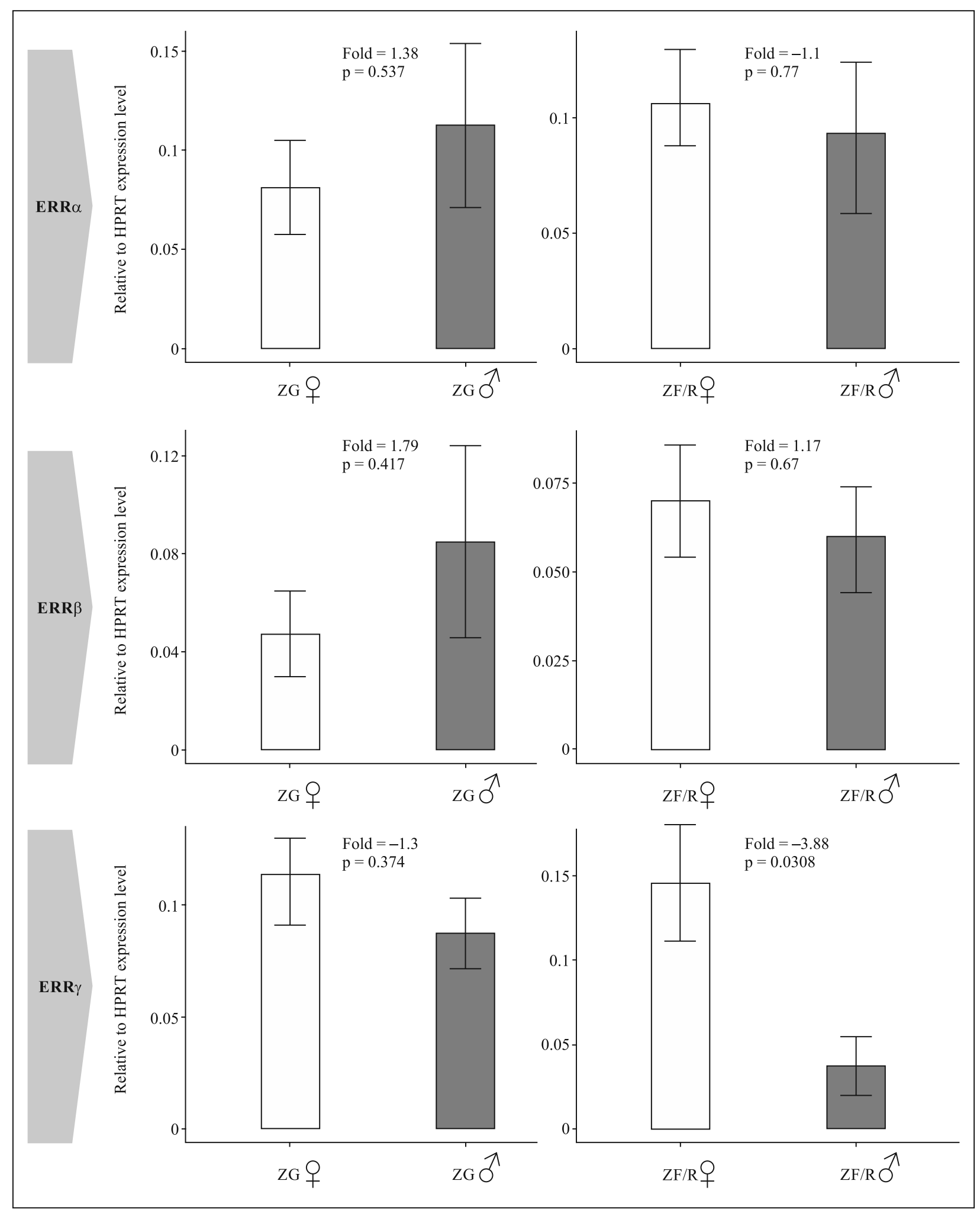

Figure 4. Expression of estrogen-related receptors (ERR $\alpha, \operatorname{ERR} \beta$ and $E R R \gamma)$ in $\mathrm{ZG}$ and $\mathrm{ZF} / \mathrm{R}$ of adult female and male adrenals. Bar plots present means of expression \pm SE, normalized to HPRT reference gene. In each group $n=4$. Data in relation to male adrenals. Fold changes and $\mathrm{p}$ values are shown 


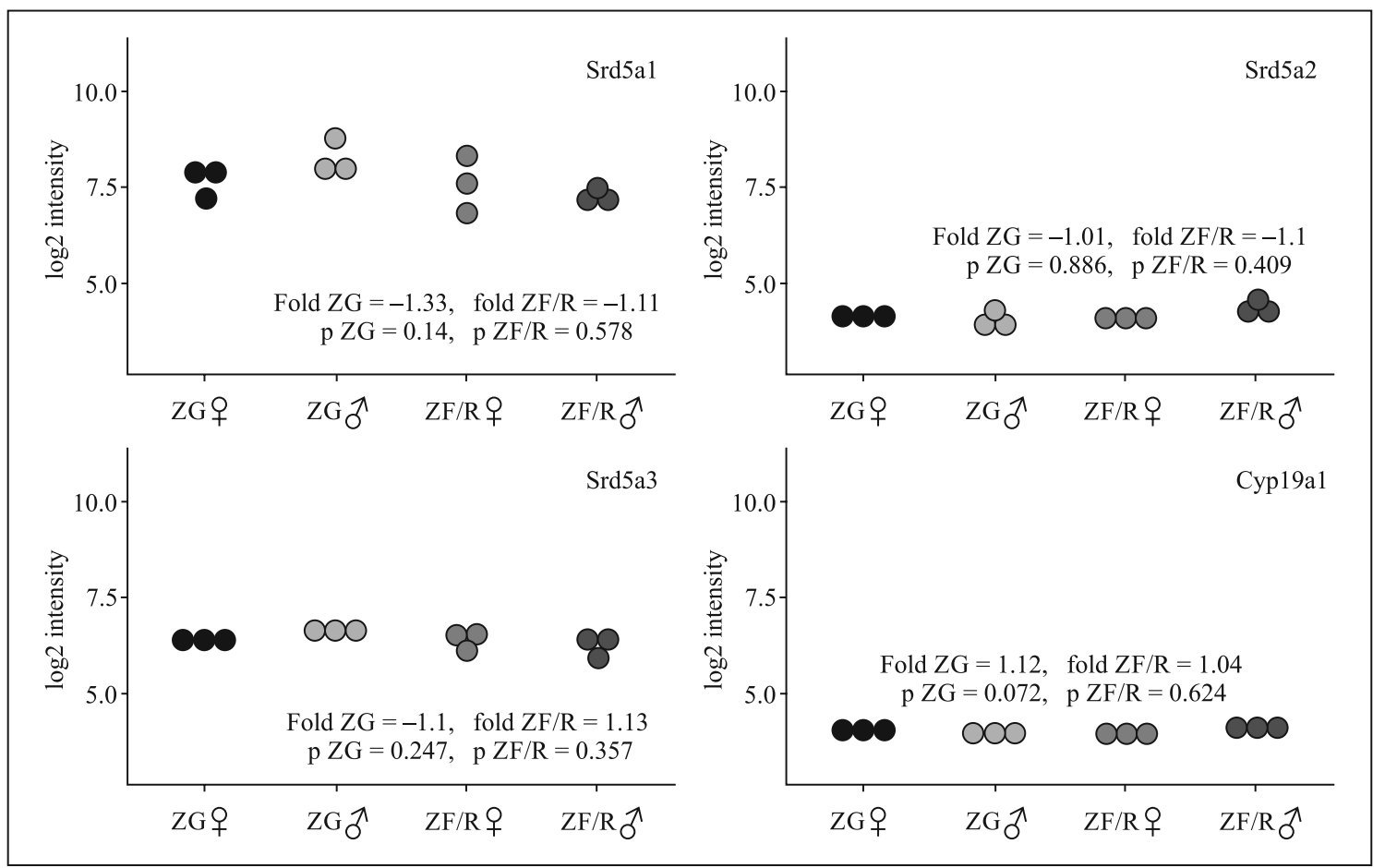

Figure 5. 5 $\alpha$-reductase isoforms (Srd5a1, Srd5a2, Srd5a3) and aromatase (Cyp19a1) genes expression in ZG and ZF/R adrenals of adult female and male rats. Normalized data obtained from Affymetrix ${ }^{\circledR}$ Rat Gene 1.1 ST Array presented as a dot-plot (plotting system for R language). From microarray data sets, expression values of Srd5a1, Srd5a2, Srd5a3 and Cyp19a1 genes were extracted. Each dot on graph corresponds to single log2-transformed value of signal intensity from individual sample (number of samples per group =3). Mean fold expression change and p values in relation to control are shown on graph. Statistical differences were determined by moderated t-statistics test with Benjamini and Hochberg's [22] false discovery rate FDR correction. Fold expression change was calculated in relation to male adrenals

in adrenals (studies on histologic slides and cytosol) of male rats [2-5]. Also by means of immunoblot assay relatively high levels of AR were detected in adrenal glands of both male and female rats [8]. By immunohistochemistry AR-like immunoreactivity was demonstrated in rat ZF and ZR while no reactivity was found in ZG and medulla of the gland [6,7]. In this regard in the sand rat AR-like immunoreactivity was demonstrated in both, ZG and ZF [26]. Only the last observation is in concord with our findings. Present QPCR studies revealed higher expression levels of $\mathrm{AR}$ gene both in $\mathrm{ZG}$ and $\mathrm{ZF} / \mathrm{R}$ of male than female rats, whereas within the same sex expression levels in $\mathrm{ZG}$ and $\mathrm{ZF} / \mathrm{R}$ were rather comparable.

Non considering GPR30, biological effects of estrogens are mediated through numerous receptor isoforms which regulate expression of target genes by binding with ERE (estrogen-responsive element) of specific genes. The first ER, now known as $\mathrm{ER} \alpha$, was cloned in 1986/1987 while ER $\beta$ in 1996 [12, 27, 28]. In adrenal cortex of different species both receptors have been identified, however, the relative expression of both receptor types differs significantly. Contrary to human adrenal cortex, in the rat adrenal cortex $\operatorname{ER} \alpha$ mRNA is far more abundant than the ER $\beta$ [29-32]. Likewise, in chicken adrenals the relative expression of $\operatorname{ER} \alpha$ mRNA was higher than $\operatorname{ER} \beta$ mRNA [33]. In the present study we confirmed expression of $\operatorname{ER} \alpha$ and $\operatorname{ER} \beta$ genes in the rat adrenal cortex. We also confirmed that in the rat adrenal cortex $\mathrm{ER} \alpha$ mRNA levels were notably higher than levels of $\mathrm{ER} \beta$ mRNA. Moreover, we demonstrated that within the same sex adrenal $Z G$ and $Z F / R$ levels of $E R \alpha$ mRNA were similar. The same concerns the levels of the $\mathrm{ER} \beta$ mRNA. Moreover, in the female $\mathrm{ZF} / \mathrm{R}$ we revealed that relative expression levels of $\mathrm{ER} \alpha / \mathrm{ER} \beta$ are notably higher than in male adrenal cortex.

As mentioned earlier, non-genomic ER (GPR30), a seven-transmembrane receptor (7TMR), is associated with rapid estrogen-dependent, $G$ protein signaling $[13,14]$. This receptor is highly expressed in the ZG and medulla of the human adrenal gland [34], in cultured bovine adrenal medullary cells [35] and in adrenal medulla of GPR30-LacZ reporter mice [36]. In the male and female rats adrenal medulla and cells within the $\mathrm{ZG}$ of the adrenal cortex, high levels 
of GPR30 mRNA and GPR30-like immunoreactivity were observed [37]. Present studies expands these earlier observation. We were able to demonstrate expression of GPR30 gene in both, the ZG and ZF/R of rat adrenal cortex. Expression levels of this gene in both compartments were similar and nearly equal in adrenals of male and female rats. It is worth to mention that the expression of the GPR30 has been recently described in the $\mathrm{ZG}$ of human normal adrenal cortex, aldosterone producing adenoma cells and in the adrenocortical HAC15 cells [31].

At present three estrogen related receptors (ERRs), $\operatorname{ERR} \alpha, \operatorname{ERR} \beta$ and $\operatorname{ERR} \gamma$, are known. Of those $\operatorname{ERR} \alpha$ and $\operatorname{ERR} \beta$ possess high sequence homology to $\operatorname{ER} \alpha$ and $\mathrm{ER} \beta$, respectively $[10,11]$. $\mathrm{ERR} \alpha$ is ubiquitously expressed and exhibits a broad range of target genes. Expression of this gene was also observed in the mouse adrenal gland [10]. Recently ERR $\alpha$ transcripts were found in the adult and fetal human adrenal glands [38]. In normal adrenals of adult humans ERR $\alpha$-like immunoreactivity was detected in all adrenocortical zones but not in the medulla. These authors suggest that $\operatorname{ERR} \alpha$ plays an important role in the regulation of adrenal steroid production. Our studies expanded earlier observations. We found the presence of ERR $\alpha$ transcripts in the $\mathrm{ZG}$ and $\mathrm{ZF} / \mathrm{R}$ of rat adrenal cortex. In both compartments expression levels of studied gene were similar and no sex-related differences could be demonstrated.

Also the second member of ERRs - ERR $\beta$ was found in the mouse adrenal gland [10]. Like in case of $E R R \alpha$, our studies revealed the presence of $\operatorname{ERR} \beta$ transcripts in the $\mathrm{ZG}$ and $\mathrm{ZF} / \mathrm{R}$ of rat adrenal cortex. And again, in both the $\mathrm{ZG}$ and $\mathrm{ZF} / \mathrm{R}$ expression levels of studied gene were similar and no sex-related differences could be demonstrated. From functional point of view it has to be underlined that mice heterozygous for $\operatorname{ERR} \beta$ deletion have increased corticosterone secretion after restraint stress, while those homozygous for $\operatorname{ERR} \beta$ deletion have higher baseline levels of this corticosteroid [39].

Expression of ERR $\gamma$, a third member of ERR, had also been demonstrated in adrenal cortex [40]. At the level of mRNA expression of this gene was demonstrated in the ZG and notably lower in the $\mathrm{ZF}$ of the mouse adrenal cortex and immunohistochemistry confirmed these findings. In our studies expression levels of ERR $\gamma$ gene were similar in the $\mathrm{ZG}$ of male and female rats, while in the ZF/R ERR $\gamma$ mRNA levels were notably lower in adult males. In this regard Luo et al. [40] suggest that ERR $\gamma$ deficiency decreases aldosterone production by reducing Cyp11b1 and Cyp11b2 expression in the mouse adrenal cortex. Furthermore, it has been suggested that $\mathrm{ERR} \gamma$ activates the DAX-1 promoter, which in turn inhibits ERR $\gamma$ through coactivator competition (an autoregulatory loop). Moreover, it was demonstrated that ERR $\gamma$ stimulates ERR $\alpha$ gene expression whereas its own gene product represses ERR $\gamma$ 's activity [41].

Our data obtained from matrix assay (not validated by QPCR) did not reveal sex related differences expression profile of three isoforms of adrenal steroid $5 \alpha$-reductase (Srd5a1, Srd5a2 and Srd5a3) in the intact rats. Of these isoforms Srd5a1 and Srd5a2 are involved in the reduction of steroids to $5 \alpha$-dihydrosteroids while $\mathrm{Srd} 5 \mathrm{a} 3$ is linked with protein glycosylation $[42,43]$. In the rat this enzyme system plays an important role in intraadrenal reduction of corticosterone to dihydrocorticosterone. As reviewed earlier [1], in the rat adrenal cortex this enzyme system is regulated by sex hormones as well as by the pituitary ACTH. As evidenced by immunohistochemistry, $5 \alpha$-reductase type 1 is expressed in the cells of the ZF and ZR but not in ZG [44]. Thus, these data differ notably from our findings showing expression of $5 \alpha$-reductase genes in both $\mathrm{ZG}$ and $\mathrm{ZF} / \mathrm{R}$ of adult male and female rats.

From matrix data (not validated by QPCR) we also analyzed expression profile of aromatase (Cyp19a1), an enzyme that catalyzes the final stage of estrogen biosynthesis pathway from androgens. In adrenals of adult rats expression levels of this gene were similar in $\mathrm{ZG}$ and $\mathrm{ZF} / \mathrm{R}$ of male and female rats. Unexpectedly, only scanty data are available on expression of this gene in normal adrenals. Aromatase expression was found in adrenal glands of fetal and newborn piglets by Western and Northern blots [45]. Immunolocalization demonstrated the highest intensity of aromatase reaction in adrenocortical cells concentrated at the corticomedullary junction and in the medulla itself. Authors suggest that these cells may represent zona reticularis, which in studied period of ontogenesis was poorly defined. In contrast to animals, numerous data are available on aromatase expression in human adrenals. Aromatase expression has been observed in the human fetal and adult normal adrenal gland [29, 34, 46]. However, expression of aromatase gene is very high in adrenocortical tumors, especially those secreting estrogens [29, 47, 48]. Moreover, functional aromatase was also identified in H295R cell line [49].

As it follows from our data and the above survey, adrenal cortex is provided with different androgen, estrogen and estrogen-related receptors. Of them, only GPR30 is non-genomic receptor while remaining receptors act on cellular DNA regulating transcription. Moreover, $\mathrm{ER} \alpha$ and $\mathrm{ER} \beta$ may form heterodimeric complexes and this may results in receptor activity distinct from that of ER homodimers [50]. Also analysis of the cross-talk within the ER/ERR subgroup of nuclear receptors revealed common targets but 
also functional differences between the two ERs [40, 51]. Close interaction between DAX-1 and ERR $\gamma$ and $\mathrm{ER} \beta$ and GPER-1 recently was also reported in HAC15 adrenocortical cell line $[31,52]$.

It is well documented that function of adrenal cortex in various species is modulated by androgens and estrogens $[1,24,25]$. In vivo their action is mainly indirect and involves modulation of the hypothalamo-pituitary-adrenocortical axis, affecting primarily $\mathrm{CRH}$ and $\mathrm{ACTH}$ synthesis and/or secretion. However, direct effects of sex hormones on adrenocortical cells, as far as they mechanisms of actions are concerned, required careful reevaluation. As documented in numerous earlier reports, both androgens and estrogens do modify steroidogenic enzyme activity when assessed in adrenal extracts ("powder") or adrenal subcellular fractions [1, 24, 53]. Also studies with short-term exposure of adrenal slices and isolated or cultured adrenocortical cells to androgens or estrogens demonstrated their ability to modulate corticosteroid output. Partially these effects depend on interference of studied sex steroids with ACTH-sensitive intracellular pathways [53-55]. However, these earlier observations do not exclude a possibility of estrogen actions through GPR30. For example, such a fast, GPR30-mediated effect of $17 \beta$-estradiol was observed in primary cultures of bovine adrenal medullary cells [35]. In this experimental model, within 20 min estradiol upregulated catecholamine synthesis.

At present, however, the newest molecular biology tools allow to study the involvement of estrogen, estrogen related and androgen receptors in sex steroid action on adrenocortical cells. In this regard results of group of Rossi [31] are fascinating. They demonstrated that in HAC15 adrenocortical cell line silencing of the $\operatorname{ER} \beta$ significantly raised aldosterone output while silencing of the GPER-1 resulted in an opposite effect. These data suggest that under physiological conditions estrogens inhibit aldosterone synthesis by acting on $\mathrm{ER} \beta$. Moreover, silencing of this gene unmasks a potent secretagogue effect on aldosterone secretion that occurs through GPER-1, non-genomic estrogen receptor.

Thus, the progress in molecular biology opens new fields in studies on mechanisms involved in estrogens and androgens actions on adrenocortical cells. Moreover, our studies confirm earlier reports that application of only one method of gene expression assessment (like microarrays) can lead to false conclusions.

\section{Acknowledgement}

This study was financed from the funds of the National Science Centre (Poland) allocated on the basis of the decision number DEC-2013/11/B/NZ4/04746.

\section{References}

1. Malendowicz LK. Cytophysiology of the mammalian adrenal cortex as related to sex, gonadectomy and gonadal hormones. PTPN Press. Poznan; 1994:1-233.

2. Müller RE, Wotiz HH. Estrogen-binding protein in mouse and rat adrenal glands. J Biol Chem. 1978;253:740-745. PMID: 621202

3. Calandra RS, Naess O, Purvis K, Attramadal A, Djoseland O, Hansson V. Estrogen receptors in rat adrenal-gland.J Steroid Biochem. 1978a;9:957-962. PMID: 745396.

4. Calandra RS, Purvis K, Naess O, Djoseland O, Hansson V. Androgen receptors in rat-adrenal gland. J Steroid Biochem. 1978b;9:1009-1015. PMID: 745391.

5. Calandra RS, Lüthy I, Finocchiaro LME, Cheb Terrab RC. Influence of sex and gonadectomy on sex steroid receptors in rat adrenal gland. J Steroid Biochem. 1980;13:1331-1335. PMID: 6969821.

6. Takeda H, Chodak G, Mutchnik S, Nakamoto T, Chang C. Immunohistochemical localization of androgen receptors with mono- and polyclonal antibodies to androgen receptor. J Endocrinol. 1990;126:17-25. PMID: 2199591.

7. Pelletier G. Localization of androgen and estrogen receptors in rat and primate tissues. Histol Histopathol. 2000;15:1261-1270. PMID: 11005250.

8. Bentvelsen FM, McPhaul MJ, Wilson CM, Wilson JD, George FW. Regulation of immunoreactive androgen receptor in the adrenal gland of the adult rat. Endocrinology. 1996;137:2659-2663. PMID: 8770883.

9. Stumpf WE. Nuclear concentration of $3 \mathrm{H}$-estradiol in target tissues. Dry-mount autoradiography of vagina, oviduct, ovary, testis, mammary tumor, liver and adrenal 1. Endocrinology. 1969;85:31-37. PMID: 581501.

10. Giguère V, Yang N, Segui P, Evans RM. Identification of a new class of steroid hormone receptors. Nature. 1988;331:91-94. PMID: 3267207.

11. Hong H, Yang L, Stallcup MR. Hormone-independent transcriptional activation and coactivator binding by novel orphan nuclear receptor ERR3.J Biol Chem. 1999;274:22618-22626. PMID: 10428842.

12. Kuiper GG, Enmark E, Pelto-Huikko M, Nilsson S, Gustafsson JA. Cloning of a novel receptor expressed in rat prostate and ovary. Proc Natl Acad Sci USA. 1996;93:5925-5930. PMID: 8650195.

13. Revankar CM, Cimino DF, Sklar LA, Arterburn JB, Prossnitz ER. A transmembrane intracellular estrogen receptor mediates rapid cell signaling. Science. 2005;307:1625-1630. PMID: 15705806.

14. Thomas P, Pang Y, Filardo EJ, Dong J. Identity of an estrogen membrane receptor coupled to a $\mathrm{G}$ protein in human breast cancer cells. Endocrinology. 2005;146:624-632. PMID: 15539556.

15. Trejter M, Hochol A, Tyczewska M et al. Sex-related gene expression profiles in the adrenal cortex in the mature rat: Microarray analysis with emphasis on genes involved in steroidogenesis. Int J Mol Med. 2015;35:702-714. doi: 10.3892/ ijmm.2015.2064.

16. Bloom JS, Khan Z, Kruglyak L, Singh M, Caudy AA. Measuring differential gene expression by short read sequencing: quantitative comparison to 2-channel gene expression microarrays. BMC Genomics. 2009;10:221. doi: 10.1186/1471-2164-10-221.

17. Qin LX, Beyer RP, Hudson FN, Linford NJ, Morris DE, Kerr KF. Evaluation of methods for oligonucleotide array data via quantitative real-time PCR. BMC bioinformatics. 2006;7:23. doi: $10.1186 / 1471-2105-7-23$. 
18. Etienne W, Meyer MH, Peppers J, Meyer RA Jr. Comparison of mRNA gene expression by RT-PCR and DNA microarray. Biotechniques. 2004;36:618-620,622,624-626. doi: 10.1016/j. tiv.2013.06.003.

19. Rucinski M, Ziolkowska A, Tyczewska M, Malendowicz LK. Expression of prepro-ghrelin and related receptor genes in the rat adrenal gland and evidences that ghrelin exerts a potent stimulating effect on corticosterone secretion by cultured rat adrenocortical cells. Peptides. 2009;30:1448-1455. doi: 10.1016/j.peptides.2009.04.016.

20. Tyczewska M, Rucinski M, Ziolkowska A et al. Enucleation -induced rat adrenal gland regeneration: expression profile of selected genes involved in control of adrenocortical cell proliferation. Int J Endocrinol. 2014;2014:130-359. doi: $\underline{10.1155 / 2014 / 130359 .}$.

21. Gentleman RC, Carey VJ, Bates DM et al. Bioconductor: open software development for computational biology and bioinformatics. Genome Biol. 2004;5:80. PMID: 15461798.

22. Benjamini Y, Hochberg Y. Controlling the false discovery rate: a practical and powerful approach to multiple testing. J R Stat Soc Ser B. 1995;57:289-300.

23. Trejter M, Hochol A, Tyczewska $M$ et al. Visinin-like peptide 1 in adrenal gland of the rat. Gene expression and its hormonal control. Peptides. 2015b;63:22-29. doi: 10.1016/j. peptides.2014.10.017.

24. Kime D, Vinson GP, Major P, Kilpatrick R. Adrenal-gonad relationship. In: McKerns KW, ed. Functions of the Adrenal Cortex. Vol 3. Academic Press, London; 1979:183-347.

25. Goel N, Workman JL, Lee TT, Innala L, Viau V. Sex differences in the HPA axis. Comp Physiol. 2014;4:1121-1155. doi: 10.1002/cphy.c130054.

26. Benmouloud A, Amirat Z, Khammar F, Patchev AV, Exbrayat JM, Almeida OF. Androgen receptor-mediated regulation of adrenocortical activity in the sand rat, Psammomys obesus. J Comp Physiol B. 2014;184:1055-1063. doi: 10.1007/s00360-014-0859-3.

27. Green S, Kumar V, Krust A, Walter P, Chambon P. Structural and functional domains of the estrogen receptor. Cold Spring Harbor symposia on quantitative biology. 1986;51:751-758. PMID: 3472759.

28. Koike S, Sakai M, Muramatsu M. Molecular cloning and characterization of rat estrogen receptor cDNA. Nucleic Acids Res. 1987;15:2499-2513. PMID: 3031601.

29. Barzon L, Masi G, Pacenti M et al. Expression of aromatase and estrogen receptors in human adrenocortical tumors. Virchows Arch. 2008;452:181-191. PMID: 18157729.

30. de Cremoux P, Rosenberg D, Goussard J et al. Expression of progesterone and estradiol receptors in normal adrenal cortex, adrenocortical tumors, and primary pigmented nodular adrenocortical disease. Endocr Relat Cancer. 2008;15:465-474. doi: 10.1677/ERC-07-0081.

31. Caroccia B, Seccia TM, Campos AG et al. GPER-1 and estrogen receptor- $\beta$ ligands modulate aldosterone synthesis. Endocrinology. 2014;155:4296-4304. doi: 10.1210/en.2014-1416.

32. Kuiper GG, Carlsson BO, Grandien KA et al. Comparison of the ligand binding specificity and transcript tissue distribution of estrogen receptors $\alpha$ and $\beta$. Endocrinology. 1997;138: 863-870. PMID: 9048584.

33. Błachuta M, Wrońska-Fortuna D. Changes in estrogen receptor $\mathrm{ER} \alpha$ and $\mathrm{ER} \beta$ expression in chicken (Gallus domesticus) adrenal gland during short-fasting and refeeding. Folia Biol. 2012;60:199-203. PMID: 23342917.

34. Baquedano MS, Saraco N, Berensztein E et al. Identification and developmental changes of aromatase and estrogen receptor expression in prepubertal and pubertal human adrenal tissues. J Clin Endocrinol Metab. 2007;92:2215-2222. PMID: 17405842.

35. Yanagihara N, Liu M, Toyohira Y et al. Stimulation of catecholamine synthesis through unique estrogen receptors in the bovine adrenomedullary plasma membrane by 17 beta-estradiol. Biochem Biophys Res Commun. 2006;13:548-553. PMID: 16307725.

36. Isensee J, Meoli L, Zazzu V et al. Expression pattern of $\mathrm{G}$ protein-coupled receptor 30 in LacZ reporter mice. Endocrinology. 2009;150:1722-1730. doi: 10.1210/en.2008-1488.

37. Hazell GG, Yao ST, Roper JA, Prossnitz ER, O'Carroll AM, Lolait SJ. Localisation of GPR30, a novel G protein-coupled oestrogen receptor, suggests multiple functions in rodent brain and peripheral tissues. J Endocrinol. 2009;202:223-236. doi: $10.1677 / \mathrm{JOE}-09-0066$.

38. Seely J, Amigh KS, Suzuki T et al. Transcriptional regulation of dehydroepiandrosterone sulfotransferase (SULT2A1) by estrogen-related receptor $\alpha$. Endocrinology. 2005;146:3605-3613. PMID: 15878968.

39. Byerly MS, Swanson RD, Wong GW, Seth Blackshaw S. Estrogen-related receptor $\beta$ deficiency alters body composition and response to restraint stress. BMC Physiol. 2013;13:10. doi: 10.1186/1472-6793-13-10.

40. Luo Y, Kumar P, Chen CC et al. Estrogen-related receptor $\gamma$ $(\mathrm{ERR} \gamma)$ serves a role in blood pressure homeostasis during pregnancy. Mol Endocrinol. 2014;28:965-975. doi: 10.1210/ me.2014-1003.

41. Zhang Z, Teng CT. Interplay between estrogen-related receptor alpha $(\operatorname{ERR} \alpha)$ and gamma $(\operatorname{ERR} \gamma)$ on the regulation of ERR $\alpha$ gene expression. Mol Cell Endocrinol. 2007;264:128-141. PMID: 17157980.

42. Cantagrel V, Lefeber DJ, Ng BG et al. SRD5A3 is required for converting polyprenol to dolichol and is mutated in a congenital glycosylation disorder. Cell. 2010;142:203-217. doi: $10.1016 /$ i.cell.2010.06.001.

43. Stiles AR, Russel DW. SRD5A3: a surprising role in glycosylation. Cell. 2010;142:196-198. doi: 10.1016/j.cell.2010.07.003.

44. Yokoi H, Tsuruo Y, Miyamoto T, Ishimura K. Steroid 5 alpha-reductase type 1 immunolocalized in the adrenal gland of normal, gonadectomized, and sex hormone-supplemented rats. Histochem Cell Biol. 1998;109:127-134. PMID: 9504773.

45. Conley AJ, Corbin CJ, Hinshelwood MM et al. Functional aromatase expression in porcine adrenal gland and testis. Biol Reprod. 1996;54:497-505. PMID: 8788204.

46. Toda K, Kilgore MW, Simpson ER, Mendelson CR, Shizuta Y, Kilgore MW. Expression of the gene encoding aromatase cytochrome P450 (CYP19) in fetal tissues. Mol Endocrinol. 1994;8:210-217. PMID: 8170477.

47. Young J, Bulun SE, Agarwal V et al. Aromatase expression in a feminizing adrenocortical tumor. J Clin Endocrinol Metab. 1996;81:3173-3176. PMID: 8784064.

48. Moreau F, Mittre H, Benhaim A et al. Aromatase expression in the normal human adult adrenal and in adrenocortical tumors: biochemical, immunohistochemical, and molecular studies. Eur J Endocrinol. 2008;160:93-99. doi: 10.1530/ EJE-08-0215.

49. Montanaro D, Maggiolini M, Recchia AG et al. Antiestrogens upregulate $\mathrm{ER} \beta$ expression and inhibit human adrenocortical cell proliferation. J Mol Endocrinol. 2005;35:245-256. PMID: 16216906

50. Pettersson K, Delaunay F, Gustafsson JK. Estrogen receptor acts as a dominant regulator of oestrogen signaling. Oncogene. 2000;19:4970-4978. PMID: 11042684.

51. Vanacker JM, Pettersson K, Gustafsson JÅ, Laudet V. Transcriptional targets shared by estrogen receptor-rela- 
ted receptors (ERRs) and estrogen receptor (ER) $\alpha$, but not by ER $\beta$. The EMBO J. 1999;18:4270-4279. PMID: 10428965.

52. Park YY, Ahn SW, Kim HJ et al. An autoregulatory loop controlling orphan nuclear receptor DAX-1 gene expression by orphan nuclear receptor ERR $\gamma$. Nucleic Acids Res. 2005;33:6756-6768. PMID: 16314306.

53. Nowak KW, Neri G, Nussdorfer GG, Malendowicz LK. Effects of sex hormones on the steroidogenic activity of dispersed adrenocortical cells of the rat adrenal cortex. Life Sci. 1995;57:833-837. PMID: 7630311.

54. Provencher PH, Tremblay Y, Bélanger A. Effects of C19 steroids on adrenal steroidogenic enzyme activities and their mRNA levels in guinea-pig fasciculata-glomerulosa cells in primary culture.J Endocrinol. 1992;132:269-276. PMID: 1311748.

55. Yanes LL, Romero DG. Dihydrotestosterone stimulates aldosterone secretion by H295R human adrenocortical cells. Mol Cell Endocrinol. 2009;303:50-56. doi: 10.1016/j.mce.2008.12.020.

Submitted: 30 January, 2015

Accepted after reviews: 8 June, 2015 Available as AoP: 9 June, 2015 